\title{
Aerosol optical depths at Mohal-Kullu in the northwestern Indian Himalayan high altitude station during ICARB
}

\author{
Jagdish C Kuniyal ${ }^{1, *}$, Alpana Thakur ${ }^{1}$, Harinder K Thakur ${ }^{1}$, Sanjeev Sharma ${ }^{1}$, \\ P PANT ${ }^{2}$, PAN S RAWAT ${ }^{3}$ and K KRISHNA MOORTHY \\ ${ }^{1}$ G.B. Pant Institute of Himalayan Environment and Development, Himachal Unit, Mohal-Kullu 175 126, India. \\ ${ }^{2}$ Aryabhatta Research Institute of Observational Sciences, Manora Peak, Nainital 263 002, India. \\ ${ }^{3}$ Department of Physics, D.S.B. Campus, Kumaun University, Nainital, Uttarakhand, India. \\ ${ }^{4}$ Space Physics Laboratory, Vikram Sarabhai Space Centre, Thiruvananthapuram 659 022, India. \\ *e-mail: kuniyaljc@yahoo.com
}

First time observations of spectral aerosol optical depths (AODs) at Mohal $\left(31.9^{\circ} \mathrm{N}, 77.11^{\circ} \mathrm{E}\right.$; altitude $1154 \mathrm{~m}$ amsl) in the Kullu valley, located in the northwestern Indian Himalayan region, have been carried out during Integrated Campaign for Aerosols, gases and Radiation Budget (ICARB), as a part of the Indian Space Research Organisation-Geosphere Biosphere Program (ISRO-GBP). AODs at six wavelengths are obtained using Microtops-II Sunphotometer and Ozonometer. The monthly mean values of AOD at $500 \mathrm{~nm}$ are found to be $0.27 \pm 0.04$ and $0.24 \pm 0.02$ during March and April, 2006 respectively. However, their monthly mean values are $0.33 \pm 0.04$ at $380 \mathrm{~nm}$ and $0.20 \pm 0.03 \mathrm{~nm}$ at $870 \mathrm{~nm}$ during March 2006 and $0.31 \pm 0.3$ at $380 \mathrm{~nm}$ and $0.17 \pm 0.2$ at $870 \mathrm{~nm}$ during April 2006, showing a gradual decrease in AOD with wavelength. The Ångstrom wavelength exponent ' $\alpha$ ' had a mean value of $0.72 \pm 0.05$, implying reduced dominance of fine particles. Further, the afternoon AOD values are higher as compared to forenoon values by $\sim 33.0 \%$ during March and by $\sim 9.0 \%$ during April 2006 and are attributed to the pollutant lifted up from the valley by the evolving boundary layer. Besides the long-range transportation of aerosol particles by airmass from the Great Sahara and the Thar Desert regions to the observing site, the high values of AODs have also been influenced by biomass burning and frequent incidents of forest fire at local levels.

\section{Introduction}

Aerosols have a direct effect on the atmospheric radiative forcing, as they scatter and absorb solar and infrared radiation in the atmosphere (Charlson et al 1992) and indirectly affect the size distribution of cloud droplets (IPCC 2001). Aerosol optical depth (AOD) is an important parameter for assessing the radiative impacts of aerosols in the atmosphere. To understand the effects of aerosols in the atmosphere, it is essential to characterize their properties at as many places as possible since they show high spatial and temporal variations, due to their regional nature and the short lifetime. In the Indian perspective, the study of aerosols has been carried out mainly through the ground based network stations of Indian Space Research Organization-Geosphere Biosphere Programme (ISRO-GBP) (Moorthy et al 1999). Generally, the high concentrations of aerosols in the atmosphere produce narrow spectrum of small cloud droplets and do not allow droplets to grow in size. As a result, rainfall is inhibited. However, if their concentration remains small in the atmosphere, the cloud condensation nuclei $(\mathrm{CCN})$ facilitate the formation of cloud droplets of proper size and precipitate (Jayaraman 2001).

The studies on columnar AODs in the northeastern as well as northwestern Himalayan regions have been very scarce. Tropospheric pollution and

Keywords. Aerosol optical depth; Ångstrom parameters; meteorological parameters; airmass back trajectories.

J. Earth Syst. Sci. 118, No. 1, February 2009, pp. 41-48

(C) Printed in India. 
prevailing humidity conditions have been the major determining factors for the columnar AODs as far as their measurements from the high altitude locations are concerned. With the concerted efforts on the part of ISRO-GBP, such aerosol climatology studies have initiated various programmes to generate a database on AODs throughout the country including the northeastern and northwestern Himalayan regions. For example, the network stations in the Himalayan regions working under ISRO-GBP are Dibrugarh in Assam (Bhuyan et al 2005; Gogoi et al 2007), Manora Peak, Nainital in Uttarakhand (Sagar et al 2004; Pant et al 2006a, b; Srivastava et al 2006), IIRS, Dehradun in Uttarakhand (Beegum et al 2008), GBPIHED, Mohal-Kullu in Himachal Pradesh (Kuniyal et al 2006; Beegum et al 2008) and Leh (3441 m) and Henle (4517 m) in Jammu \& Kashmir (Singh and Singh 2004), where measurements of AODs with the help of Multi-wavelength Radiometers (MWR-SPL make) or Microtops-II (Solar Light Co. USA make) are being conducted.

An integrated campaign for aerosol, gases and radiation budget (ICARB) was conducted under ISRO-GBP during March to May 2006. The ICARB was conceived as an integrated campaign comprising of three segments namely the land, ocean, and aircraft. The land segment involved the ground-based ISRO-GBP network stations for the aerosol observations, whereas spatially resolved measurements were made on the moving platforms involving the remaining segments. Further, the main emphasis of this campaign was given to study the physical, chemical, and optical characteristics of aerosols and trace gases as well as their temporal and spatial variations in the regional levels.

\section{Experimental setup and database}

\subsection{Experimental sites}

The present study has been carried out at Mohal $\left(31.9^{\circ} \mathrm{N}, 77.11^{\circ} \mathrm{E}\right.$; altitude $\left.1154 \mathrm{~m} \mathrm{amsl}\right), 5 \mathrm{~km}$ south of Kullu, a tourist spot in the Kullu valley of northwestern Himalayas in the state of Himachal Pradesh. The Kullu valley starts from the south at Larji $(957 \mathrm{~m})$ in the lower Beas valley up to the Rohtang crest $(4038 \mathrm{~m})$ in the upper Beas basin. The Kullu valley is bisected by the River Beas and extends up to $80 \mathrm{~km}$ long and $2 \mathrm{~km}$ wide. Based on micro-climatic conditions, the whole valley geographically falls into two parts, namely the upper Kullu valley and the lower Kullu valley. Raison is a location, which divides this valley into two parts. The sub-Kullu valley south of Raison falls in a rain shadow zone where the present experimental site, Mohal is located. Kullu $(1219 \mathrm{~m})$, a tourist spot, is close to the present experimental site. Mohal (Kullu) falls under sub-temperate climate and occupies an area of about $7 \mathrm{~km}^{2}$ with a native population of 18,306 in 2001 (Census of India 2001) having a floating population of about 24,000 visitors per day during the peak of summer season (Kuniyal and Vishvakarma 2006).

Due to rapidly growing urbanization in the recent past, the surrounding environment in the immediate vicinity of the experimental site is dominated by tourism and agro-horticultural activities. Soil dust, vehicular emissions, forest fires and other biomass burning activities mainly for cooking and heating purposes in and around the experimental site have contributed significantly to increase the concentration of different types of aerosols over this region. In addition to this, contributions arise from wind blown dust, aerosols, attributed mainly to the long-range transport of aerosols through airmasses as well as from local sources.

\subsection{Prevailing meteorology}

The prevailing meteorological characteristics have also been examined with the help of Automatic Weather Station (Wind Monitor, WM-251, make Envirotech). Daily meteorological data were collected on an hourly basis. These hourly data were averaged to find the diurnal value of various meteorological parameters. Overall, 2134 hourly samples at Mohal from January to June 2006 were collected to draw a wind-rose. Figure 1(a-f) shows the meteorological conditions at Mohal. The highest temperature recorded during the campaign was $19^{\circ} \mathrm{C}$ on 24 April 2006 (figure 1a). The relative humidity was lowest with $55.4 \%$ on April 15, 2006 followed by $56.1 \%$ on March 8, 2006 and $56.8 \%$ on April 12, 2006 (figure 1b). The lowest relative humidity at Mohal was recorded with $24 \%$ on April 11, 2006. The prevailing wind pattern during the campaign is shown by figure $1(\mathrm{c})$. The wind at Mohal is under light strong breeze category ranging between $\sim 14$ and $\sim 17 \mathrm{~km} \mathrm{~h}^{-1}$ during second and third week of April 2006 (figure 1d). Figure 1(e) shows yearly wind pattern, which is being usually found at the experimental site. The wind-rose reveals that for majority of days the wind is received from the northwesterly direction at the experimental site. During campaign, the maximum rainfall was recorded on March 13, 2006 with about $37 \mathrm{~mm}$ followed by about $25 \mathrm{~mm}$ on April 15, 2006 and $20 \mathrm{~mm}$ on April 10, 2006 (figure 1f).

\subsection{Aerosol optical depth measurements}

The present observations of AODs were obtained by using Microtops-II (Solar Light Co, USA), 

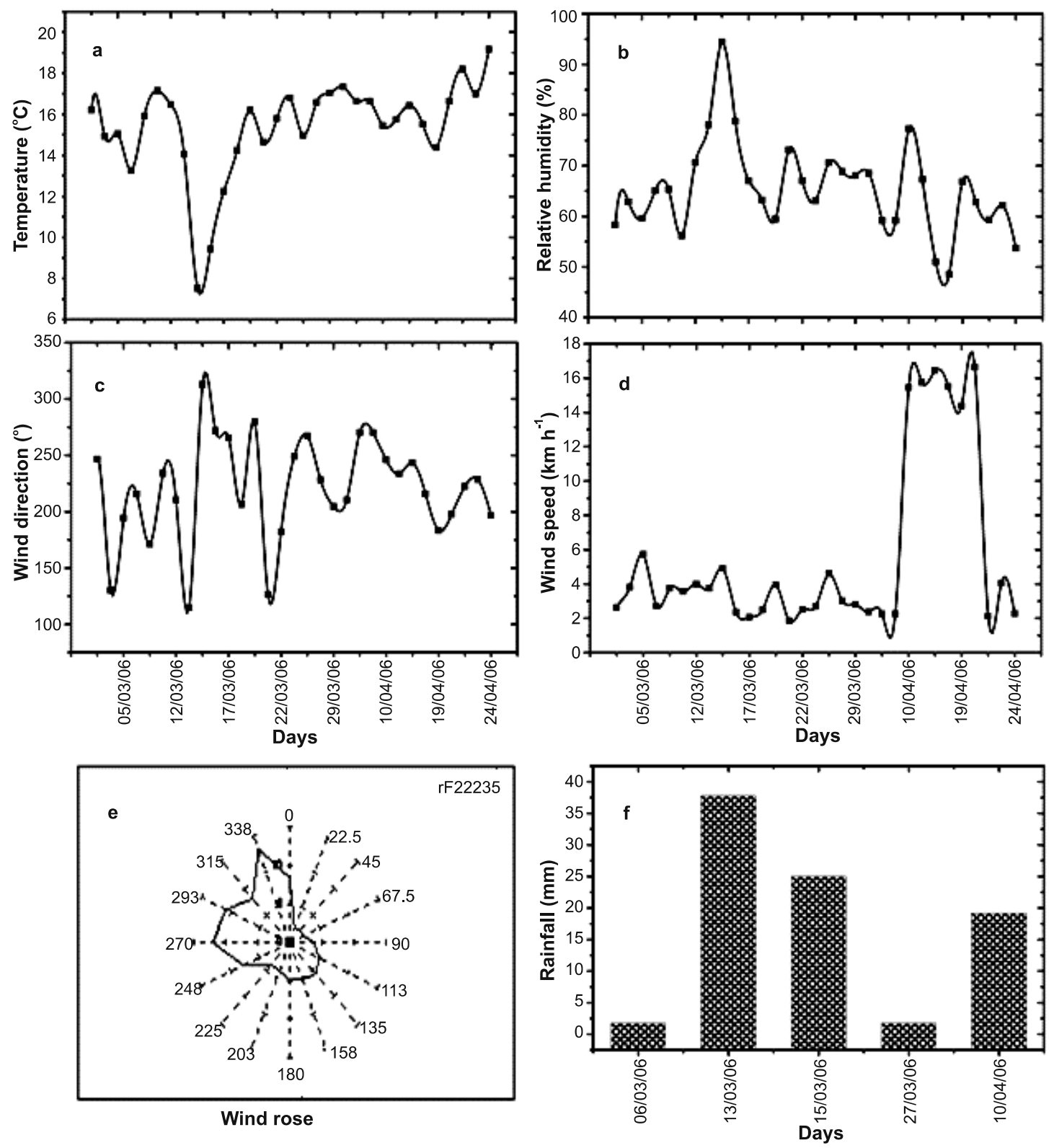

Figure 1. Meteorological parameters at Mohal: (a) temperature, (b) relative humidity, (c) wind direction, (d) wind speed, (e) wind-rose, and (f) rainfall.

Sunphotometer and Ozonometer. These are handheld photometers that measure direct solar radiations and give instantaneous columnar AODs (at six wavelengths centered at 380, 440, 500, 675, 870 and $1020 \mathrm{~nm}$ with a bandwidth of 6 to $10 \mathrm{~nm}$ ), water vapour content (W) and total columnar ozone (TCO) based on their initial calibration. Observations were taken approximately at half an hour interval from sunrise to sunset whenever the sky was clear or partly clear and no visible clouds were present in the neighbourhood of the solar disc. The performance and methodology of data acquisitions with Microtops-II have been described by Morys et al (2001) and Ichoku et al (2002). The total number of datasets of AOD measurements were available for 38 days (from March 3, 2006 to April 24, 2006).

\section{Results and discussions}

\subsection{Aerosol optical depths}

Daily mean variations of the estimated aerosol optical depths are shown in figure 2. The daily mean of AOD values are higher at shorter wavelengths than at longer wavelengths. Analyzing these AOD for a representative wavelength of $500 \mathrm{~nm}$ shows a significant variation in AOD for forenoon (FN) and afternoon (AN) periods of the 


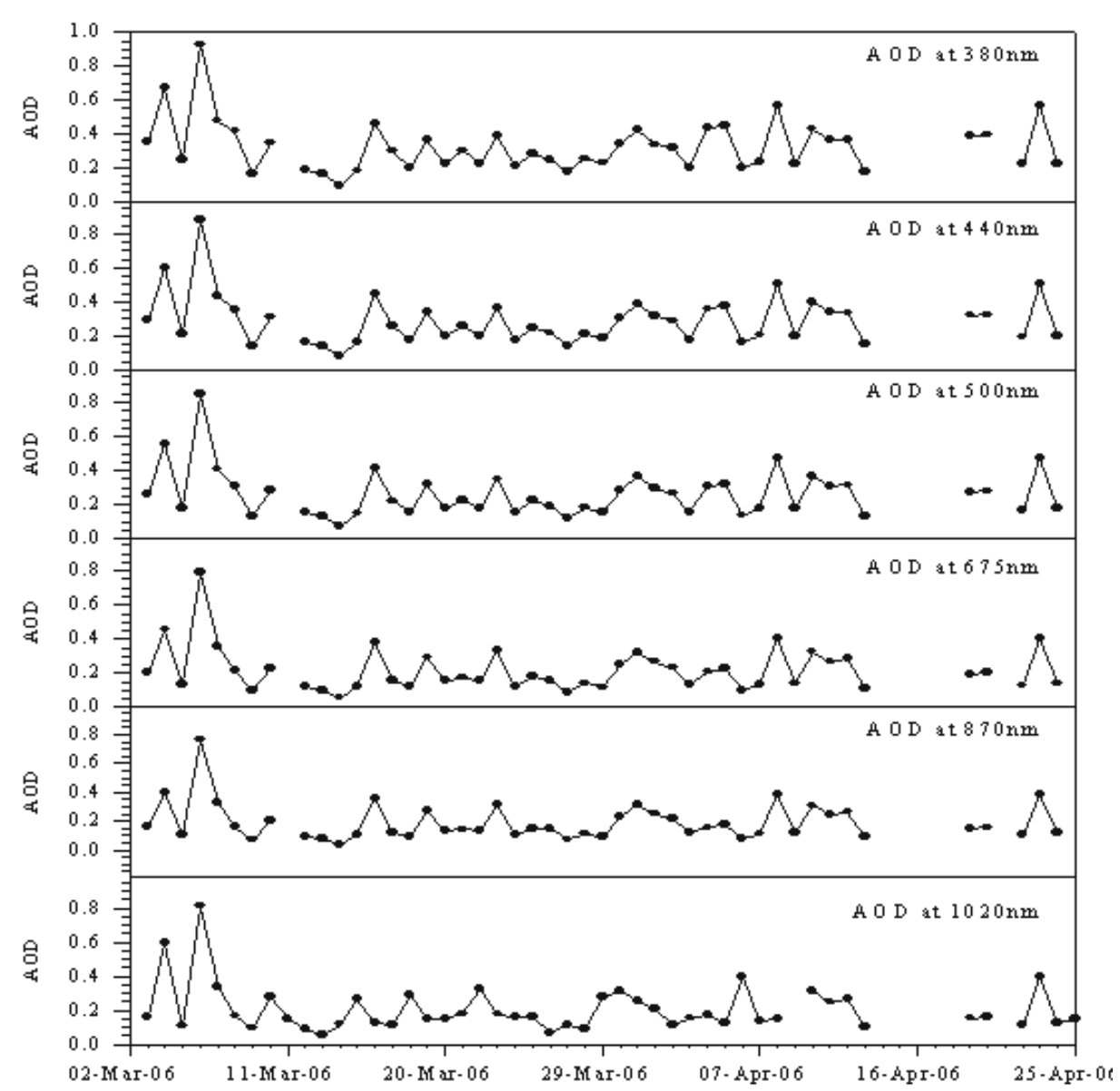

Figure 2. Daily mean variations in AODs at different wavelengths (380-1020 nm).
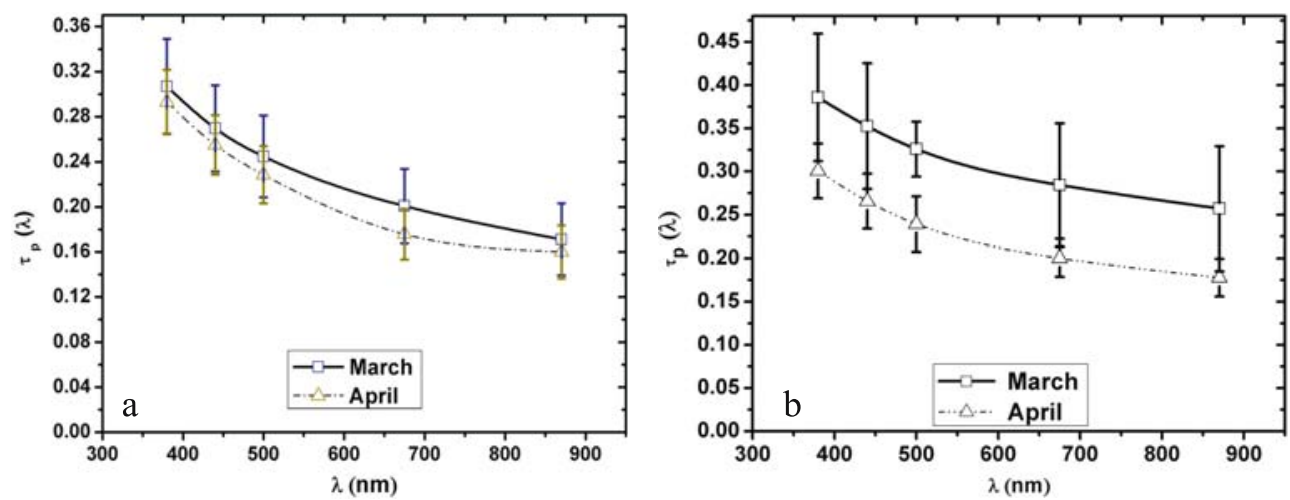

Figure 3. Variations in (a) forenoon (FN) and (b) afternoon (AN) AODs for different wavelengths.

same day. The range of variations during the whole observation period were from 0.085 (March 17) to 0.787 (March 4) for the FN period and from 0.063 (March 17) to 1.57 (March 6) for the AN period. The highest daily mean of AOD was found to be 0.843 on March 6, 2006. These remarkably higher values of AODs are attributed to the long range transported aerosols due to the airmasses from the Sahara and the Thar Deserts to the observing site. In addition to this, the impact of western disturbances that are accompanied with the flow of airmasses, which are also prolific in the region during the winter, is considered to be responsible for the frequent variations in AODs during the local winter months. Spectral variations of the mean of FN and AN AODs during March and April 2006 have been shown in figure 3(a and b). The FN value of AOD (at $380 \mathrm{~nm}$ ) is found to be $0.31 \pm 0.04$ and $0.29 \pm 0.29$ during March and April 2006 respectively (figure 3a), whereas the AN 


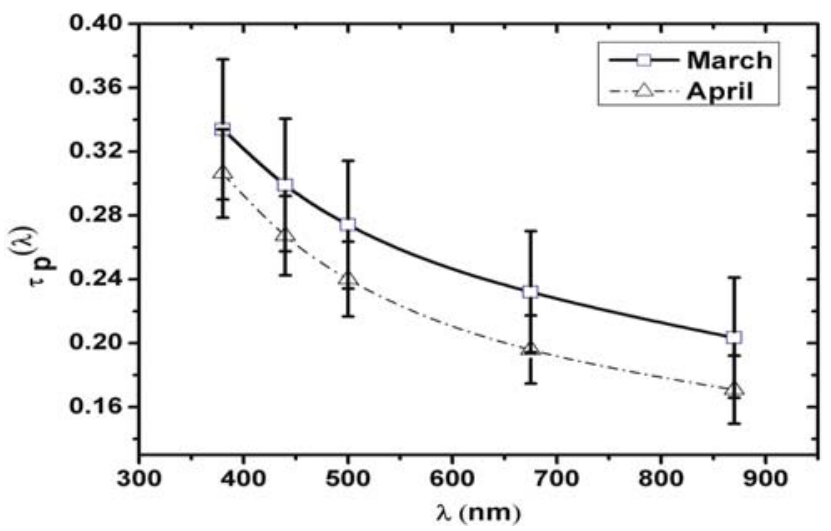

Figure 4. Monthly mean variations in AODs for different wavelengths.

values at the same wavelength showed $0.39 \pm 0.07$ and $0.30 \pm 0.03$ during March and April 2006 respectively. Accordingly, this shows an increase of $\sim 26 \%$ and $\sim 4 \%$ from $\mathrm{FN}$ to $\mathrm{AN}$ during the months of March and April, 2006 respectively. These observations indicate that the FN-AN differences in AOD reduce towards summer months where the afternoon values at the same wavelength remained $0.33 \pm 0.03$ and $0.24 \pm 0.03$ during these two months. Similar trends are seen at other wavelengths too. As the observation site is wellelevated, it is possible that during winter months, the AOD measurements are made from above the atmospheric boundary layer, at least during the morning periods. As the solar heating of the land increases, with the advance of the day, convective eddies develop and strengthen. These lift-up the pollutants, including aerosols, from the valley below which eventually break the capping inversion and get distributed to the higher levels, causing an enhancement in the concentration of aerosols in the afternoon. Similar effects are reported from other Himalayan regions also (Pant et al 2006b). As summer advances, the minimum land temperature increases and the ABL and even the nocturnal layer deepens, so that the peak would be well within the daytime ABL for most of the time, and the $\mathrm{FN}-\mathrm{AN}$ difference decreases.

\subsection{Angstrom parameters}

The spectral variation of aerosol optical depths shows higher values at shorter wavelength and then decreases in accordance with an increase of the wavelengths (figure 4). It complies in harmony with the Mie scattering theory for aerosols distributions.

It is well known that spectral variation of AODs contains information pertaining to their size distribution (Satheesh et al 2001). A simple way of expressing the wavelength dependence of AOD is

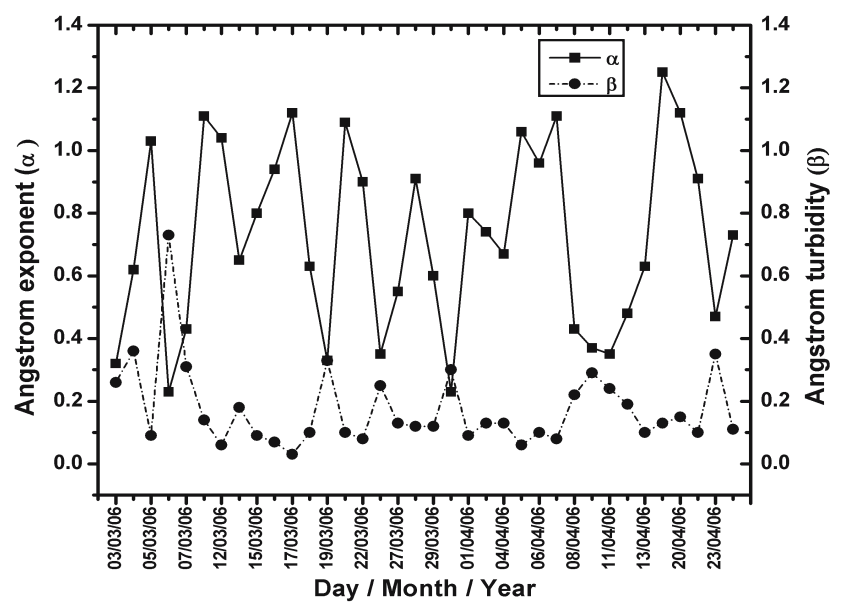

Figure 5. Variations in Ångstrom wavelength exponent $(\alpha)$ and turbidity parameter $(\beta)$.

through the Ångstrom relation (Ångstrom 1964), expressed as under:

$$
\tau_{p \lambda}=\beta \lambda^{-\alpha},
$$

where $\tau_{p \lambda}$ is the spectral AOD as a function of wavelength $(\lambda), \beta$ is the turbidity coefficient representing the total aerosol loading in the vertical column, $\alpha$ is the Angstrom exponent related to the size distribution and depends on the ratio of the concentration of small to large aerosols (Ångstrom 1964; Shaw et al 1973; Shaw 1976). By evolving an empirical fit of the measured AOD spectra to the Angstrom power law, the Ångstrom wavelength exponent $(\alpha)$ and turbidity coefficient $(\beta)$ were estimated (figure 5). The higher values of Ångstrom wavelength exponent $(\alpha)$ imply abundance of super micron aerosols (Satheesh et al 2001). The values of $\alpha$ were found to be in the range 0.23 to 1.3 with a mean value of $0.72 \pm 0.05$. This is considerably lower than those reported for urban continental region of India and elsewhere, when the mean $\alpha$ for the period is typically $>1.0$. The low value of ' $\alpha$ ', resulting in a flat AOD spectrum indicating a relatively low abundance accumulation mode aerosols of anthropogenic, due to the remote nature of the site.

\subsection{Airmass back trajectory analysis using HYSPLIT model}

For exploring the possible reasons for the extreme AODs as a consequence of aerosols loading at the site, the Hybrid Single-Particle Lagrangian Integrated Trajectory (HYSPLIT) model was followed (Draxler and Rolph 2003). To understand long range transport of aerosols with the airmasses in the region, back trajectories have been able to 
NOAA HYSPLIT MODEL

Backward trajectories ending at 06 UTC 04 Mar 06

FNL Meteorological Data

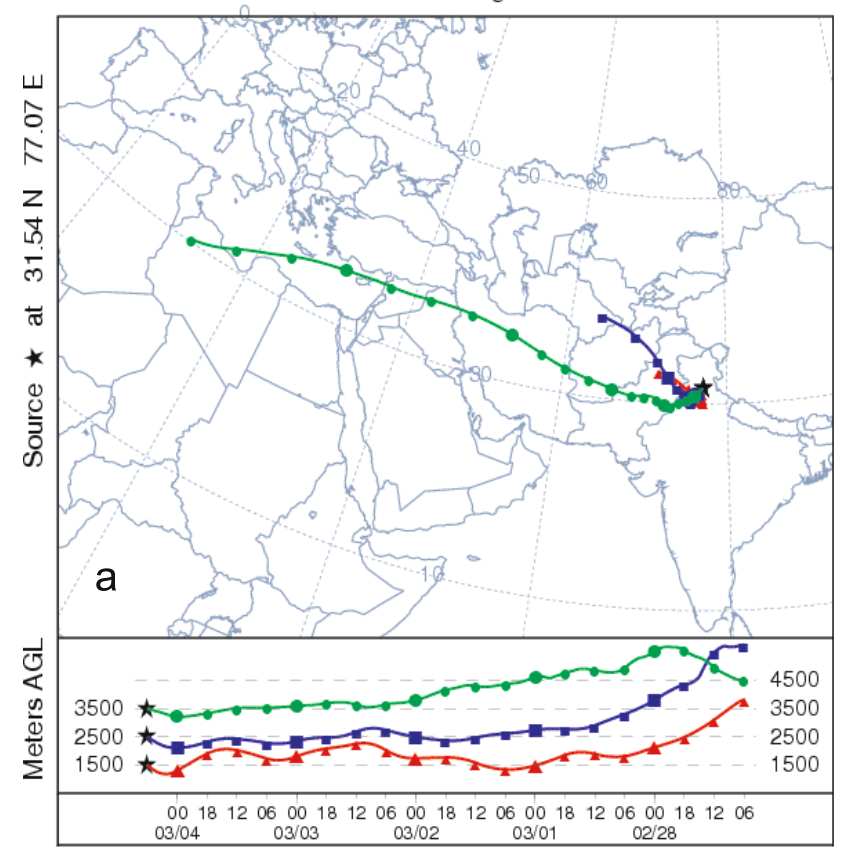

NOAA HYSPLIT MODEL

Backward trajectories ending at 06 UTC 10 Apr 06 FNL Meteorological Data

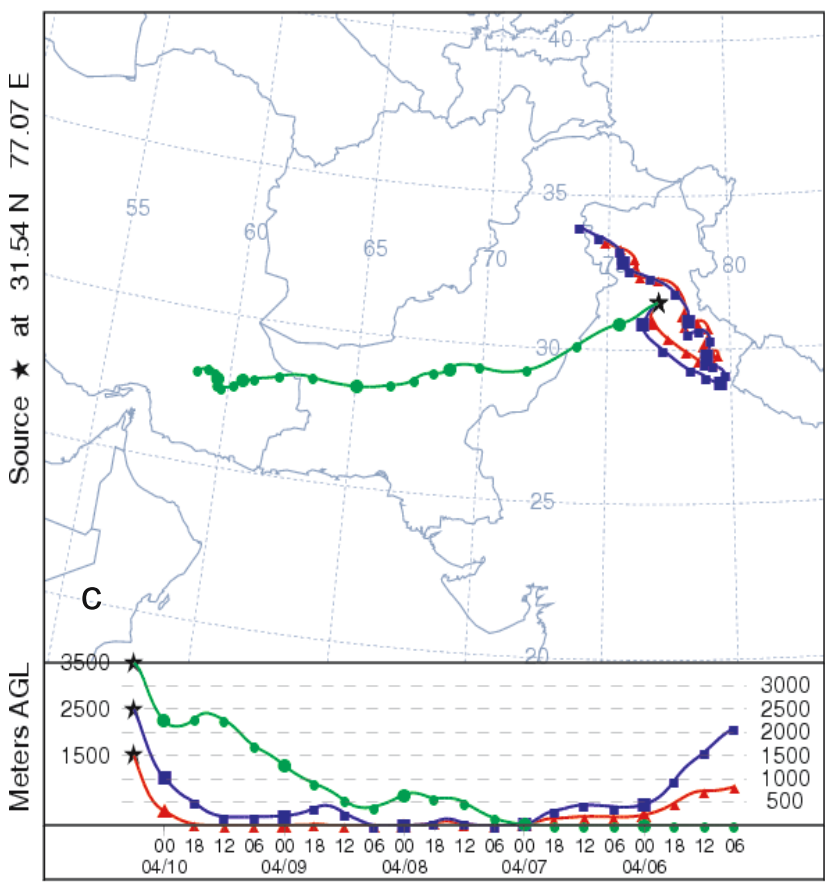

NOAA HYSPLIT MODEL

Backward trajectories ending at 06 UTC 06 Mar 06

FNL Meteorological Data

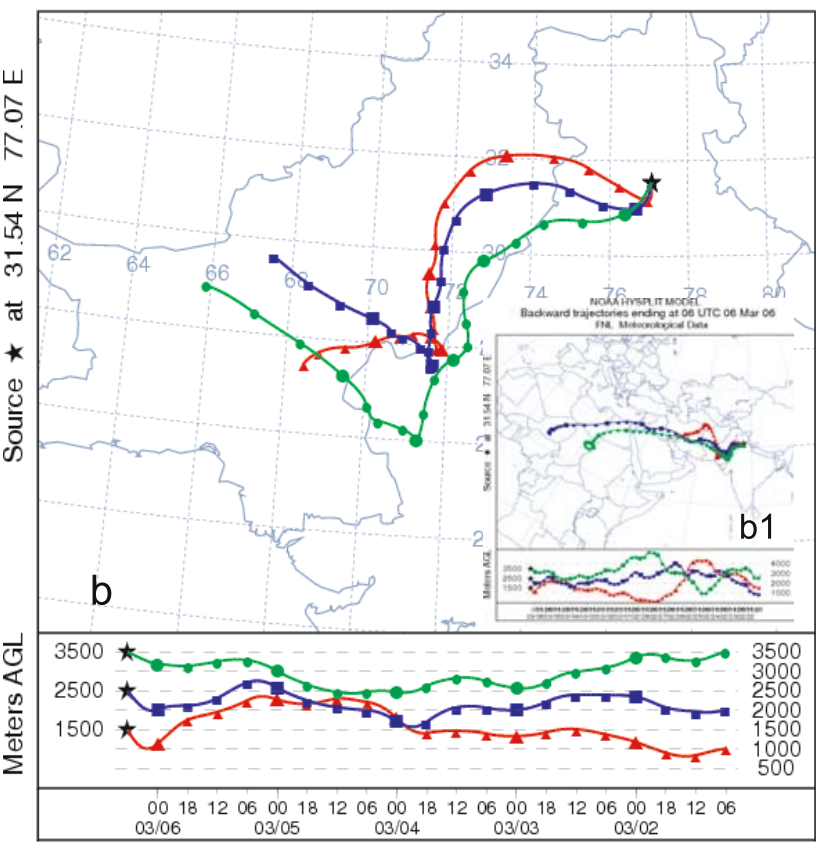

NOAA HYSPLIT MODEL

Backward trajectories ending at 06 UTC 23 Apr 06 FNL Meteorological Data

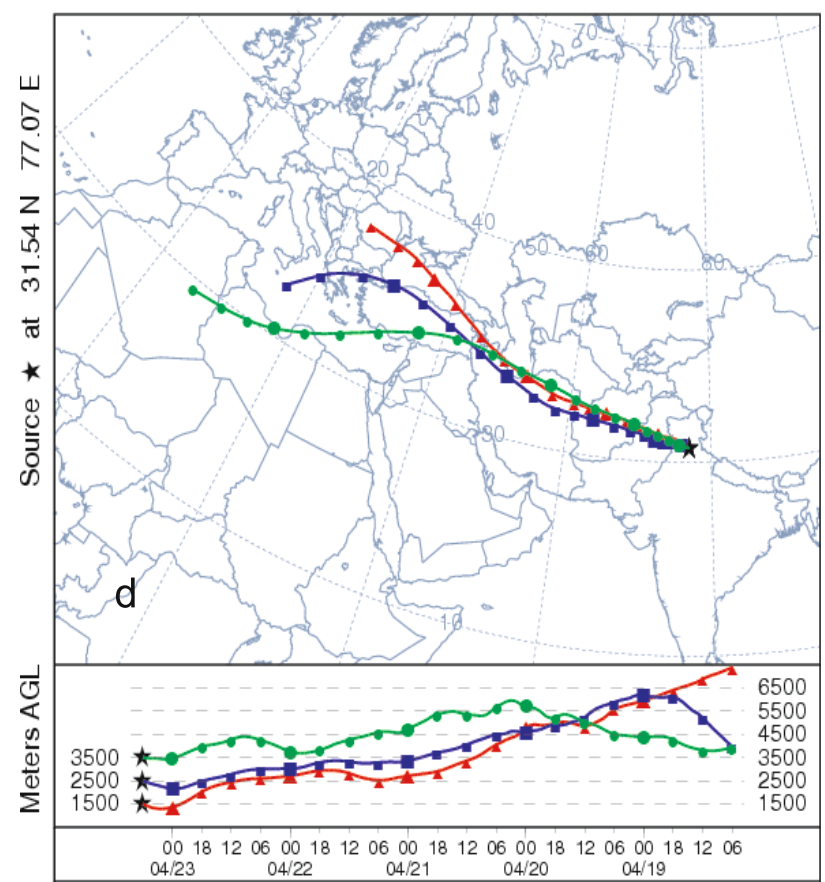

Figure 6. Backward trajectories ending at 06 UTC at Mohal on: (a) March 4, 2006, (b) March 6, 2006, (c) April 10, 2006, and (d) April 23, 2006.

indicate the original sources of airmasses. Five days back trajectories ending at Mohal at 1130 IST at different altitudes of 1500,2500 and $3500 \mathrm{~m}$ above the ground level (AGL) were analyzed for March 4 and 6, 2006 and April 10 and 23, 2006 (figure 6). On these days, the observed AODs were exceptionally high. Most of the back trajectories coming to the experimental site seem to be airmass flow from Sahara, sub-Sahara regions and Great Thar Desert region of Rajasthan. These airmasses bring the fine dust particles in the high altitude regions of Mohal, which are mainly responsible for a significant rise 
in AOD values and lower value of ' $\alpha$ '. One of the back trajectories at $1500 \mathrm{~m}$ (AGL) was almost less than $400 \mathrm{~m}$ above the height of the experimental location at Mohal. This height is almost within the mixing height boundary layer for most of the time, influencing the concentration of aerosols in the region.

\section{Conclusion}

The observations of spectral AODs during ICARB are carried out for the first time from a sparsely inhabited region at Mohal in the Kullu valley of Himachal Pradesh. It is located in the northwestern part of Indian Himalayan region. During the campaign, the monthly mean AOD values at $500 \mathrm{~nm}$ have been found as $0.27 \pm 0.04$ and $0.24 \pm 0.02$ for the months of March and April 2006 respectively. Temporal variations in the spectral AOD values are found to be higher in March in comparison to April 2006 at all wavelengths. The moderately higher AODs during March 2006 seem to be largely influenced by anthropogenic aerosols at local level and also by the long-range transported dust from the outside regions into the experimental site. In this perspective, the airmass back trajectory analysis also shows that the major source of fine aerosols that are transported to the observing site are from the Sahara as well as the Thar Desert regions.

\section{Acknowledgements}

The authors are thankful to the Directors of three respective Institutes - G.B. Pant Institute of Himalayan Environment and Development (GBPIHED), Kosi-Katarmal, Almora (Uttarakhand), Aryabhatta Research Institute of Observational Sciences (ARIES), Nainital (Uttarakhand) and Space Physics Laboratory (SPL), Vikram Sarabhai Space Research Centre, Thiruvananthapuram (Kerala) for encouraging inter-institutional collaborative research programmes and providing facilities in their respective institutes to complete the present study successfully. The first author also thanks the ISRO, Bangalore for providing financial assistance to conduct this research work as a separate short-term ad hoc R\&D project. The authors sincerely thank the reviewers for their useful comments and suggestions, which significantly improved the content of the paper.

\section{References}

Ångstrom A 1964 Techniques of determining the turbidity of the atmosphere; Tellus 13 214-223.
Beegum S Naseema, Moorthy K K, Nair V S, Babu S S, Satheesh S K, Vinoj V, Reddy R R, Gopal K R, Badarinath K V S, Niranjan K, Pandey S K, Behera M, Jeyaram A, Bhuyan P K, Gogoi M M, Singh S, Pant P, Dumka U C, Kant Y, Kuniyal J C and Singh D 2008 Characteristics of spectral aerosol optical depths over India during ICARB; J. Earth Syst. Sci. 117(S1) 303-313.

Bhuyan P K, Gogoi M M and Moorthy K K 2005 Spectral and temporal characteristics of aerosol optical depth over a wet tropical location in North East India; Adv. Space Res. 35 1423-1429.

Census of India 2001 Provisional Population Totals - Part 2; Director of Census Operations, Government of Himachal Pradesh, Shimla, pp 1-79.

Charlson R J, Schwartz S E, Hales J M, Cess R D, Coakley Jr J A, Hansen J E and Hoffmann D J 1992 Climate forcing by anthropogenic aerosols; Science $\mathbf{2 5 5}$ 423-430.

Draxler R R and Rolph G D 2003 HYSPLIT (Hybrid Single-Particle Lagrangian Integrated Trajectory) software, NOAA; Air Resour. Lab., Silver Spring, Md. (available at http://www.arl.noaa.gov/ready/hysplit4.html).

Gogoi M M, Bhuyan P K and Moorthy K K 2007 Possible impact of a major oil-well fire on aerosol optical depth at Dibrugarh; Curr. Sci. 92(8) 1047-1049.

Ichoku C, Levy R, Kaufman Y J, Remer L A, Li R-R, Martins V J, Holben B N, Abuhassan N, Slutsker I, Eck T F and Pietras C 2002 Analysis of the performance characteristics of the five-channel Microtops II Sun photometer for measuring aerosol optical thickness and precipitable water vapor; J. Geophys. Res. 107(D13) 4179, doi:10.1029/2001JD001302.

IPCC 2001 International Panel on Climate Change (IPCC); The Scientific Basis, Cambridge University Press, New York.

Jayaraman A 2001 Aerosol radiation cloud interactions over the tropical Indian Ocean prior to the onset of the summer monsoon; Curr. Sci. 81(11) 1437-1445.

Kuniyal J C, Thakur Alpana, Tripathi Smita, Thakur H K, Sharma S, Oinam S S, Pant P, Hegde P and Dumka U C 2006 Aerosols characteristics at high altitude locations of Kullu-Manali in the northwestern Himalaya during ICARB; In: Proc. First Post-Campaign meeting of ICARB \& Meeting of the WG-II of ISRO-GBP, Geosphere Biosphere Programme (I-GBP). Space Physics Laboratory, VSSC, Thiruvanthpuram, October 25-27, pp 1-232.

Kuniyal J C and Vishvakarma S C R 2006 Changing behaviour of ambient air quality and surface ozone in hill spots: a case study of Kullu-Manali Tourist Complex (KMTC), Northwestern Himalaya; DST final technical report submitted to the Department of Science \& Technology, Govt. of India, November 2006, pp 1-36.

Morys M, Mims F M III, Hagerup S, Anderson S E, Baker A, Kia J and Walkup T 2001 Design calibration and performance of Microtops II handheld ozone monitor and Sun photometer; J. Geophys. Res. 106(D13) $14,573-14,582$.

Moorthy K K, Niranjan K, Narasimhamurthy B, Agashe V V and Murthy B V K 1999 Aerosol climatology over India; 1-ISRO-GBP MWR network and database, ISRO-GBP SR-03-99.

Pant P, Hedge P, Dumka U C, Saha A, Srivastava M K and Sagar R 2006a Aerosol characteristics at a high-altitude location during ISRO-GBP Land campaign-II; Curr. Sci. 91(8) 1053-1061.

Pant P, Hegde P, Dumka U C, Sagar R, Satheesh S K, Moorthy K K, Saha A and Srivastava M K 2006b 
Aerosol characteristics at a high-altitude location in central Himalayas: Optical properties and radiative forcing; J. Geophys. Res. 3 D17206, doi: 10.1029/2005JD006768. Sagar R, Kumar B, Dumka U C, Moorthy K K and Pant P 2004 Characteristics of aerosol optical depths over Manora Peak: A high altitude station in the central Himalaya; J. Geophys. Res. 109 006207, doi: 10.1029/2003JD003954.

Satheesh S K, Moorthy K K and Das I 2001 Aerosol spectral optical depths over the Bay of Bengal, Arabian Sea and Indian Ocean; Curr. Sci. 81 16-18.

Shaw G E 1976 Error Analysis of Multi-wavelength Sun Photometry; Pure Appl. Geophys. 114 1-14.
Shaw G E, Reagan J A and Herman B M 1973 Investigations of atmospheric extinction using direct solar radiation measurements made in the multiple wavelength radiometer; J. Appl. Meteorol. 12 374-380.

Singh S and Singh R 2004 High altitude clear sky direct solar ultraviolet irradiance at Leh and Henle in the western Himalayas: Observations and model calculations; J. Geophys. Res. 109 D19201, doi 10.1029/2004JD 004854.

Srivastava M K, Singh S, Saha A, Dumka U C, Hegde P, Singh R and Pant P 2006 Direct solar ultraviolet irradiance over Nainital, India, in the central Himalaya for clear-sky day conditions during December 2004; J. Geophys. Res. 111 D08201.

MS received 8 June 2007; revised 3 October 2008; accepted 6 October 2008 